\title{
8. Achieving greater access: a new role for established legal principles?
}

\author{
Abbe E.L. Brown
}

\subsection{INTRODUCTION}

This chapter discusses the extent to which different legal fields might be combined to make a substantive contribution to the battle against climate change. Firstly, how can intellectual property (IP), competition and human rights, separately and together, assist in identifying essential technologies? Secondly, if the goal in respect of climate change should not be access to essential technologies but the generation of and use of more technologies of all kinds, what role can be played by IP, competition and human rights? Finally, it will be argued that greater access to some climate change-related technologies is required - and when this is so, what is the place of the three fields in delivering this? This chapter will focus on solutions which could be developed in the European Union (EU). It is of course the case, as recognized throughout this collection, that climate change has implications well beyond the EU. Yet the EU is a sophisticated legal environment; if a solution exploring the interface between these three fields cannot be developed there, this may suggest that the approach is not of wider global relevance.

\subsection{TOWARDS ESSENTIAL TECHNOLOGIES}

\subsubsection{Could There Be an Essential Climate Change Technology?}

Throughout this project, a question has been raised frequently: what is an essential technology? A state seeking to address climate change in the light of its Kyoto Protocol obligations in relation to reduction of greenhouse gas emissions ${ }^{1}$ might seem to be faced with a wider range of options. They might wish to pursue more development of technologies which could assist in relation to mitigation, with more use of renewable 
energy sources (such as wind, wave and biogas) rather than carbon fuels; in relation to adaptation, they could encourage the development of new seeds and new medicines which would work in the light of the changes which have resulted from climate change; and they could also look to measuring mechanisms to assist in evaluation. ${ }^{2}$

In a particular situation, there may not always be so many options. In the north of Scotland, say, there is not much public transport and more need to drive; colder weather, so more need for heating; and less reliable sunshine. This suggests that the possible existence of essential technologies warrants further analysis. Yet as considered in this collection by Culver (see Chapter 1), there are arguments that the priority should be the development of more technologies of all kinds which can be relevant to responding to all aspects of the climate change problem. From this it could be argued that all of the technologies introduced above are essential. The next sections will consider three possible means of identifying essential technologies, using the three legal fields.

\subsubsection{Option 1: solving a problem (or an IP approach?)}

The basic elements of IP As has been explored elsewhere in this collection by Santamauro and McGrory, intellectual property rights (IPRs) conferred by national $\mathrm{law}^{3}$ can be a form of encouraging innovation and solving problems. ${ }^{4}$ This might suggest that IP should be left to do its job and that more technologies would result. It is interesting to note, as discussed by Santamauro, that attempts are being made in a number of jurisdictions to ensure that patent applications which relate to the climate change field can be reviewed more quickly. ${ }^{5}$ Yet once the innovator or creator obtains IP, then they can control the use of the technology and limit its dissemination and transfer. This control is restricted by time, ${ }^{6}$ geography, ${ }^{7}$ activities ${ }^{8}$ and, ultimately, the extent to which demand is met with the prospect of there being a compulsory licence, as discussed by Santamauro in this collection. ${ }^{9}$ The impact of this control is considered in more detail later in this chapter, but it does suggest that relying on IP to encourage innovation could have some negative consequences. Of more immediate interest to the essential technologies question, however, are the initial threshold requirements (which vary across IPRs) which must be met for the rights to exist.

Narrowness of IP IP rights exist under an international umbrella, with the main instrument now being TRIPS, which is part of the WTO Agreements, ${ }^{10}$ and which refers to some other international agreements. ${ }^{11}$ Most states are parties to TRIPS. ${ }^{12}$ The principles set out in TRIPS, 
which are then embedded in states' national laws, require the innovation to be original, ${ }^{13}$ novel, inventive and capable of industrial application, ${ }^{14}$ and not in an excluded category (which has been the focus of some attention in relation to IP). ${ }^{15}$ These tests are applied with a focus on the innovation and creativity in question, and (consistently with at least one of the underlying aims of IP $)^{16}$ with a desire to reward the innovator and creator. These tests do not involve any external consideration of the value to be added to society by the development; they also do not consider any possibly wasteful duplication.

For a right to exist, therefore, one need not have regard to whether or not a technology in itself (or in conjunction with others, as discussed by Tuncak in this collection ${ }^{17}$ solves apparently minor problems, such as providing a superior form of packaging: ${ }^{18}$ or can make a more substantial contribution to society, such as providing a means of delivering renewable power throughout a country. ${ }^{19}$ This legal blindness means that there may be other forms of meeting the same climate change needs - other solutions to the problem. These solutions could in turn also gain their own IP, if they meet the tests, but they might not or IP might not be relevant; for example, a family could reduce their carbon footprint by wearing more layers of clothes, rather than burning coal, or no IP right may exist in respect of the form of creativity, e.g., in respect of the collation of data sets in the United States. ${ }^{20}$ This suggests that seeing IP as the main form of encouraging or recognizing innovation and solutions will leave some developments unrewarded and leave open the possibility of duplication.

IP in itself, therefore, does not provide a means of identifying whether or not a technology is essential. The second of the doctrines to be explored here, competition, may be of more assistance.

\subsubsection{Option 2: there is no other solution (a competition approach?)}

Possible examples The relevance of competition can be explored through a discussion of two examples of possible essential technologies. The first is geo-spatial data and measurement tools. In the digital age, control of information has moved to companies, see, for example, Google Streetview ${ }^{21}$ or the Automobile Association's website. ${ }^{22}$ If IP is sought or relied upon in respect of these data sets, say copyright or database rights (where available), or products are developed using them, then access to fundamental information about society could be limited.23 In some situations, a state and public body ${ }^{24}$ can be required to disclose information, for example, in the United Kingdom through the Freedom of 
Information Act $2000 .{ }^{25}$ Yet even if a request can be made, IP can still restrict the use which may be made of information. ${ }^{26}$

The second set of examples of essential technologies could be a set of software which operates the network grid, through which providers deliver power. At present the most effective uses of renewable energy involve communities generating and using power themselves, ${ }^{27}$ and systems for wider delivery would need to work with the existing grid. Yet owners of IP in an existing system could prevent the joining of others and they could also determine the future direction of the innovation, as there is no point in developing a system which cannot connect to the existing one. Analogies can be drawn here with questions of access to docks and railways and, in the digital age, the Microsoft operating system, all of which are discussed in more detail below.

This issue of working together also raises the question of 'standards', which were considered by Culver in this collection, in the discussion of future energy networks. This term can cover methods for assessing the environmental impact of information and communication technologies, ${ }^{28}$ and also the technical means of achieving them. It is the latter which is of most interest here. The setting of standards may be helpful, as it would be clear to all who wish to work in an industry which materials or qualities should be used, and to know that users and other providers who may be interested in using their products would find them compatible and interoperable with their own and with others.

A particular technology which is the subject of IP may be part of a standard, including open standards ${ }^{29}$ (which are a wide and evolving term).$^{30}$ If so, the IP owner can be in a position of power, given the extent to which others will choose, or may be required, to use their technology. ${ }^{31}$ In the light of this, organizations might require that members of the standard disclose IP which is relevant to the standard; and also that information which is essential ${ }^{32}$ to meeting the standard will be licensed to other members of the standard or more widely. This may be for free, but more likely in return for a payment of a fair, reasonable and nondiscriminatory royalty; and if this is not done there may be procedures regarding ongoing membership and alterations to the standard. ${ }^{33}$ The meaning of 'fair, reasonable and non-discriminatory' can be difficult to evaluate outside specific factual and commercial circumstances, and it is interesting to note that at the time of writing in 2012, this is being considered by the International Telecommunications Union. ${ }^{34}$

In the energy field, industry bodies frequently set formal standards, such as the Storage Networking Industry Association (which has released a Green Storage Power Measurement Technical Specification) ${ }^{35}$ as do 
international bodies, such as the International Standards Organization which is active in relation to environmental management standards. ${ }^{36}$ Another important example is Sunspec, in the photovoltaic industry. ${ }^{37}$

\subsubsection{Review}

Do these examples really support the possible existence of essential technologies? It can be argued that if underlying data is controlled by companies or states who do not wish to disclose it, then others could be creative and go and identify it themselves; or could build a new delivery system; or create an alternative standard and seek to attract all those presently in the industry, by offering a better service and lower prices. In response, arguments can be made based on cost, time, regulation and user intransigence. How compelling are these arguments? An answer lies in competition.

\subsubsection{Power of Competition Law}

Competition law concerns the behaviour of operators in a market. Broadly, and in contrast with IP discussed above, competition law will be used by regulators or courts if there is conduct which has an anticompetitive effect; it is this, rather than the question of reward of innovators, which is the central question for competition law. There is a complex relationship between competition and IP: are they in conflict, as competition may abhor the private exclusivity accorded by IP, or are they different forms of progressing towards the same ultimate aim, of encouraging innovation and benefit to consumers? ${ }^{38}$ And even if competition and the rights of an IP owner are viewed as conflicting in a particular situation, this can only have a practical impact if there is an actual competition law. There is no competition equivalent of TRIPS, but there is a developed competition law in the EU and these provisions are now part of the Treaty on the Functioning of the European Union (TFEU). Of present interest, this addresses abuse of a dominant position on the basis of Article 102 TFEU, which is considered here, and anti-competitive agreements, which are considered later in this chapter. Other competition issues are considered by McLean in this collection.

Courts and regulators have been willing to use the prohibition on abuse of a dominant position to interfere with the conduct of IP owners. This has been so, however, only in exceptional circumstances, ${ }^{39}$ given the complex relationship between IP and competition and also, in the EU context, the prohibition on the interference with property rights, which includes IP. ${ }^{40}$ There have been findings of abuse when IP owners have engaged in the very conduct which is at the heart of the IP right - 
refusing to license as it wishes (which is considered in more detail below $)^{41}$ and raising an infringement action. ${ }^{42}$ There have also been investigations regarding seeking the right in the first place, ${ }^{43}$ and the refusal to license, on appropriate terms, information technology sets and software which are the subject of IP and part of a standard. ${ }^{44}$

Abuse questions could also arise if there is an informal standard, one based not on industry agreement but rather through being a technology which others choose to use rather than any other. This might be because it is of the highest quality; it might be because it is one with which they are most familiar or it might be because if they do not use it they will not be able to communicate with others, as it has become entrenched in the industry and with consumers, in a network effect. ${ }^{45}$ Courts have also been prepared to limit the remedies which would be available in any infringement action when IP is part of a standard, if there has been an offer to take a licence at a reasonable rate ${ }^{46}$ but this is a controversial issue and it will be interesting to note how this develops.

The abuse of a dominant position legislation has been used to require the sharing of essential infrastructure and standards such as that discussed above (using the umbrella term 'the essential facilities doctrine'). An essential facility has been considered to arise if access to the infrastructure is indispensable for someone to compete in the market, in the sense that there is no commercially reasonable alternative, e.g., competition with the incumbent and dominant railway operator, and there is no justification on the basis of cost, capacity and legitimate business purpose. ${ }^{47}$ The essential facilities doctrine has been part of discussion by scholars, and Advocates-General of the ECJ, regarding the interface between IP and competition for some time; ${ }^{48}$ however, there has been no reference to the doctrine in decisions in this field. It is interesting to note that in a case involving price information and horse racing, the underlying data was considered to be an essential facility ${ }^{49}$ and although no cases have yet arisen involving technology and the environment, this last example might be the closest analogy.

But for this to be relevant, the IP owner would need to be in a dominant position in a market. And it is this assessment of the market, and the relevance of other potential options, which are most important for the present discussion of essential technologies. The relevant EU guidelines, which build upon established case law, require regard to be had to substitutes from the supply and demand perspectives in relation to the technology which is the subject of the IP, the prospects of substitutes being developed within an appropriate time (with network effects, the nature and importance of innovation in the field, the extent to which the technology forms part of a product, and the existence of IP being 
considered) and also geography. ${ }^{50}$ It must then be determined if the IP owner is in a dominant position: could they act to an appreciable extent independently of others? ${ }^{51}$ If they are the only member of a market, then clearly they will be in a dominant position.

As the only member of a market, it can be argued that they are also essential. Competition provides, therefore, a clear means of identifying what might be an essential technology. It does so by addressing the place of technologies within the present and anticipated reality. But does a competition approach proceed from the wrong starting point? Should the question in identifying an essential technology depend not on what the present innovation environment has brought or is likely to bring about, but what it should seek to achieve? In the light of this, the next section will consider identifying essential technologies from this final perspective of goals which they seek to achieve. Human rights will be the means of exploring this. ${ }^{52}$

\subsubsection{An Essential Objective (Using Human Rights?)}

As has been noted in this collection by Onazi, by Morgera and Kulovesi and by Tuncak, human rights can be approached from theoretical and instrumental perspectives: this collection has discussed dignity and justice $^{53}$ and also that international instruments provide for rights to life, ${ }^{54}$ food, ${ }^{55}$ health, ${ }^{56}$ and also in respect of the reward of the innovator and access to the benefits of scientific progress. ${ }^{57}$ There is also growing discussion regarding human rights and the environment. ${ }^{58}$ In the EU, the European Convention on Human Rights, which forms part of the fundamental rights of the EU, ${ }^{59}$ includes rights to life, expression and property (which has been found to include IP). ${ }^{60}$ There is also the EU Charter (which, since the Lisbon Treaty, has the same legal value as the treaties $)^{61}$ and this includes a specific reference to IP, ${ }^{62}$ and provides that the EU must integrate into its policies a high level of environmental protection as well as improvement to the quality of the environment. ${ }^{63}$ Further, the Lisbon Treaty also enshrines the established principles and rights which 'result from the constitutional traditions common to the Member States'. ${ }^{64}$ Case law has found this to include rights in international treaties (such as those considered above), on which the Member States have collaborated or to which they are signatories. ${ }^{65}$

This range of sources and arguments may make human rights seem more entrenched, particularly in the EU, than IP and competition. Further, although as is considered below there are limited enforcement procedures available in respect of human rights, EU institutions (including the competition regulator, the European Commission) must have 
regard to fundamental rights in their decision-making. ${ }^{66}$ Yet if a decisionmaker looks to human rights in a matter, what would they find?

More than one human right could arise in a climate change situation. There could be rights to life or to food in respect of wider access to a seed which would grow in drought ridden parts of rural southern Europe (of interest to questions raised by Onazi and Tuncak), and rights to property and possible reward in respect of a patent or plant variety right which might exist in respect of it. Guidance exists from national courts and also from international bodies with regard to how to address conflict between human rights. ${ }^{67}$ At the heart of this is the need for balance and proportionality. This is not always a straightforward exercise. ${ }^{68}$ And once the decision is made, there may be more than one technology which could deliver the objective - say, more than one seed which could in fact grow to deliver food and enhance life. Does this mean that they are both or all to be treated as 'essential'?

\subsection{THE PLACE FOR A COMBINED APPROACH}

The discussion so far has revealed the different outcomes which could result from using IP, competition or human rights as shorthand for identifying essential technologies. More would be gained by combining the fields. Human rights can ultimately identify the goal in mind; IP can encourage the development of technologies which can deliver this; and competition can provide a means of identifying if there is only one technology which can deliver the goal or if there is a relevant substitute. If there is no substitute, the technology can be deemed to be essential.

This proposal for identifying essential technologies makes it worthwhile to discuss how greater access can be provided to them. This is the subject of the final section of this chapter. Yet firstly it must be borne in mind that the proposals made will identify essential technologies very rarely. Further, the nature of the proposals means that the identification process cannot be a central part of the innovation and climate change framework - rather it must exist at the boundary, as a means of resolving extreme situations. And in any event, technologies which are not essential can still be important for steps taken against climate change, as has been discussed by Culver and Davies in this collection. Is there a role for IP, competition and human rights in seeking to bring about wider access more generally? This will be explored in the next section. 


\subsubsection{Further Steps Towards Sharing}

As is explored elsewhere in this collection, by Culver, Davies and Santamauro, there are other forms of encouraging innovation which do not depend on the exercise of control by IP owners. Arguments can be made for a more organic and fluid approach, one which enables ongoing interaction and mutual learning and development. Open standards can clearly have a key role in this, and from the EU perspective there have been significant projects exploring how best to encourage innovation, through the Lisbon Innovation research and innovation agenda, ${ }^{69}$ its successor EU 2020, ${ }^{70}$ and in particular the Competitiveness and Innovation Programme of the European Commission 2007-2013. ${ }^{71}$ As part of this, the Entrepreneurship and Innovation Programme ${ }^{72}$ places some emphasis on IP in its Support for Innovation policy ${ }^{73}$ as does the Europe 2020 Flagship Initiative Innovation Union (EU2020) launched in October $2010 .^{74}$ The Innovation Union also considers the importance of stand$\operatorname{ards}^{75}$ and openness, ${ }^{76}$ as does the EU 2020's Digital Agenda for Europe $^{77}$ and the Information and Communications Technology policy support $^{78}$ work programme of $2011^{79}$ refers to standards and interoperability.

Globally, there has been increasing willingness to share in each of the climate change, information technology and pharmaceutical fields. Three interesting examples are the Eco-Patent Commons (as discussed in this collection by Davies) Creative Commons in relation to software, ${ }^{80}$ and agreements between companies and the Drugs for Neglected Diseases initiative, which are considered in this collection by Santamauro. ${ }^{81}$ These initiatives still involve the choice by an IP to take a different approach to how they will use their IP; and it is still possible for the IP owner to choose to take a more traditional approach to IP. Nonetheless, these initiatives suggest that new approaches can be adopted to innovation, avoiding a confrontation with IP as a whole, as there was at international level to the introduction of compulsory licensing frameworks in the health and climate change fields. ${ }^{82}$

The growing recognition of and support for open standards and the sharing of innovation more generally could have important consequences for states in their actions against climate change. A state in the EU which is member of the Kyoto Protocol (and the EU itself) has obligations regarding the reduction of emissions. A state could choose to require that all technology which it chooses to fund in respect of mitigation, adaptation or measurement should be made available to all, either for free (with the state instead paying the provider), or for a reasonable fee. Likewise, the state could require that the grid delivery systems operate 
using software which is made available on an open standard, making it easier for new generators of power to turn it into deliverable electricity. ${ }^{83}$ Developers of new seeds, vaccines, medicines and forms of harnessing renewable energy sources may also choose themselves to combine and share their technology - possibly for a payment, on reasonable terms, or possibly not, building on existing initiatives such as the Eco-Patent Commons. This might seem attractive from an innovation and climate change perspective - but are there legal obstacles?

\subsubsection{Relevance of Human Rights, IP and Competition}

\subsubsection{IP and human rights}

From the IP perspective, open standards and sharing of technology need not be problematic. It is the choice of the IP owners to take a particular approach to their control of the technology. From the state perspective, encouragement of open standards does not mean that a state is not complying with its obligations under TRIPS in respect of providing forms of protection for IP. From the human rights perspective, given the element of choice on the part of the IP owners, it could not be argued that open standards are inconsistent with the reward element of IP, nor with the IP owners' human rights to property and possibly to IP. Further, open standards will lead to technology being more widely available and so may result in greater delivery of life, health and protection of the environment.

\subsubsection{Competition: agreements}

Competition law is more problematic. The making of open standards and setting the terms on which the technology is to be made available will involve agreements. As noted above, EU competition law deals with some forms of agreement. Article 101 TFEU provides that some agreements ${ }^{84}$ are prohibited and void. ${ }^{85}$ This could include standards agreements relating to the licensing arrangement which encourage interoperability, which have special rules for members of an organization, or which apply to all who wish to use technology. Yet Article 101(3) provides that the prohibition can be declared inapplicable in respect of agreements which contribute to improving the production or distribution of goods or to promoting technical or economic progress, while allowing consumers a fair share of the resulting benefit', and which do not impose a substantial limit on competition and restrictions which go beyond this objective.

As noted in this chapter, there are strong arguments which can be made in favour of particular forms of licensing and dissemination, and 
the wider benefits which can arise for innovation and society in terms of its immediate use and its contribution to the development of new products. ${ }^{86}$ In the EU, the European Commission issues block exemptions and guidelines to assist business and its advisers in assessing if an agreement is prohibited. In 2011, these include block exemption arrangements and sets of guidance relating to technology transfer and licensing of IP. ${ }^{87}$ These $^{88}$ do make some references to standards and in this respect also discuss open standards, although this receives less attention. ${ }^{89}$ Further, in 2010 the European Commission issued draft guidelines on the application of Article 101 to horizontal cooperation agreements. ${ }^{90}$ These sought to introduce a new regime for their treatment under EU competition law, ${ }^{91}$ were expressly stated to cover agreements relating to environmental standards, and included some examples regarding IP and environmental standards and state encouraged environmental standards. ${ }^{92}$ They noted the benefits which can arise from the more open approach to standard setting, particularly when all those who wish can be involved in the setting of the standard and being a member of the organization. ${ }^{93}$ In the consultation which followed the draft guidelines, ${ }^{94}$ scholars argued for guidelines which more specifically addressed standards, ${ }^{95}$ and the Digital Europe response endorses the references made to an open approach, stressing the risks which can arise from IP, and calling for more focus on open standards. ${ }^{96}$

The resulting final guidelines ${ }^{97}$ do address formal standards and openness. ${ }^{98}$ They also consider that standards based on nondiscriminatory, open and transparent procedures would not be prohibited. ${ }^{99}$ A gap remains for guidance which focuses specifically on standards. In 2012, therefore, the EU competition framework relevant to standards is still in a state of evolution and it will be interesting to note how this proceeds. Open standards and their relationship with environmental issues do seem a possible part of the future.

\subsubsection{Summary}

This section has noted a growing role for sharing and open standards in innovation, with some examples of activities involving climate change technologies. It has also been seen that, once again, the three legal fields can make different and interlinking contributions to the validity of the approach. An open standard could deliver outcomes consistent with human rights, is not inconsistent with TRIPS and could be permitted by competition law. An option exists, therefore, for encouraging greater 
development of technology and wider use of it. This discussion, consistent with other chapters in this collection, supports a new approach to innovation.

Yet a significant question remains. A state may choose not to encourage a more open approach, particularly given the strong ongoing voice of IP in the international community. ${ }^{100}$ And even if a government chooses one path, a company may not follow, and choose rather to invest in other forms of innovation or activity, as considered in this collection by Jones. The issue of the power of an IP owner in some situations would therefore remain and the question raised earlier in this chapter arises again: once an essential technology has been identified, how could wider dissemination be required? Jones also argues that there is a need for an expeditious response to climate change and that obstacles and requirements for sharing should not be imposed. This may be so in most cases. But delivering more access in the rare cases when an essential technology has been identified can address more widely the same needs as those which would be addressed by the development of technologies - reduction of emissions.

\subsection{REQUIRING ACCESS}

\subsubsection{Forum}

So if there is to be a new approach to requiring access to essential technologies, where should this be carried out? Previous outputs of the project discussed the taking of action, possibly through declarations or new approaches to dispute settlement, at WIPO (as proposed in this collection by Santamauro), WTO, UN human rights bodies or in the UNFCCC. There was a wide range of views as to which forum is most appropriate,$^{101}$ and an issue of present importance is the limited dispute resolution powers of some, most notably the UN human rights monitoring bodies. ${ }^{102}$ There is also the question of whether or not it would be preferable for a new tribunal to be established, where the rich interface between the fields could be explored on a more neutral footing, rather than this seeking to be done within an existing legal body which may be more familiar with some doctrines and approaches than others. Would a new EU forum requiring sharing be viable? 


\subsubsection{A New EU Tribunal}

We have seen that the EU has competition law, some IP law and an established system of balancing national IP law with EU competition law. It also has an established and developing framework of human rights to which decision-makers must have regard. It further has a wide range of relevant expertise, including the Regulatory Board and Board of Appeal of the Agency for the Cooperation of Energy Regulators, launched in 2011:103 in addition the European Commission has Directorates-General dedicated to competition and enterprise and industry (referred to above), for the environment ${ }^{104}$ and climate action, ${ }^{105}$ and there is the Agency for Fundamental Rights. ${ }^{106}$ It could be proposed that a new tribunal is created, combining this expertise, the IP, competition and human rights laws and the responsibilities of the EU as a signatory of the Kyoto Protocol. ${ }^{107}$

Applications could be made to the tribunal by companies who consider that they need to use a particular technology in their work in the battle against climate change, explaining how it would deliver human rights. They would need to establish why they needed this technology and no other, that they had asked the owner of the IP right and that their request had been declined. They would also need to show how much they were able to pay for the technology. The tribunal could determine whether it would require sharing, and what terms (high payment? low payment? no payment?) would be appropriate. The making of a payment to the provider would provide them with some reward for their innovation and investment.

Yet, just as the EU can provide some legal opportunities, it can, as was seen in relation to agreements, provide legal obstacles. All the power held by the EU and its institutions has been conferred by treaty: if there is no relevant power, then the EU cannot take the proposed steps. A relevant example of the impact of this was the attempt to set up a Community Patent Court, to address the present need for parallel patent actions to exist throughout the EU in respect of very similar technologies and parties. The full Court of Justice opined that this was inconsistent with EU law ${ }^{108}$ and a new approach has been taken through the unified patent package. ${ }^{109}$ Here, therefore, EU law would likely prevent the establishing of a new tribunal. It should also be borne in mind that it would be likely to take some time to establish a new tribunal, bearing in mind that proposals regarding the Community Patent Court had been ongoing since the Community Patent Convention 1975. 


\subsubsection{Using an Existing Tribunal}

\subsubsection{Which one?}

So, a new tribunal is unlikely to be a tenable proposal. Yet, could the same objective, of the making of a decision on access to technologies having regard to the full range of laws which have been argued to be relevant, be achieved by an existing decision-maker? Within the EU context, IP questions are considered by the Court of Justice on references from national courts in IP infringement actions regarding the interpretation and implementation of Directives and Regulations, ${ }^{110}$ and could be made in respect of the availability of competition defences, although this has not yet been done. ${ }^{111}$ To pursue a request for access by this route, therefore, one would need to have embarked on infringing conduct and invited the court action. Claims based on breach of human rights, say, as a result of the enforcement of the IP right, cannot be made directly to the Court of Justice, although if national remedies are exhausted it is possible for a complaint then to be made to the European Court of Human Rights. ${ }^{112}$ The closest analogy to the proposal for a new tribunal would lie in competition law, the European Commission - and possibly a new role for the essential facilities doctrine.

\subsubsection{A new role for the European Commission?}

The first step would be a complaint to the European Commission that request had been made for an IP licence and that this had not been provided, either at all, or on what the seeker considered reasonable terms. This is what was done by Sun Microsystems at the start of the Microsoft investigation. The Commission will choose whether or not to investigate, and it must be borne in mind that it does not always investigate, and there are questions regarding its own resource. ${ }^{113}$

If it chooses to investigate, the competition action will proceed as discussed in relation to defining essential technologies. The market will be defined, and as we have seen, regard will be had to whether or not there are substitutes within the relevant geographical area and the likelihood of substitutes arising. As noted above, if an IP owner is in a dominant position (possible even if there are others in the market), sharing can be required if there has been an abuse of a dominant position. The test which has been developed by the courts and the European Commission refers to material being used to meet consumer demand in a (possible hypothetical) other market which would not otherwise be fulfilled; to a likelihood of elimination of competition if there was no licence; to a lack of objective justification for the refusal; and a need for information the subject of the IP to be indispensable to enable the person 
seeking access to develop a new product or bring about a technical development. ${ }^{114}$

This last element of the test may not be met in cases seeking access to a technology to use it for its very purpose, and requests for essential technologies are likely to be of this nature. It could be argued that all work in the climate change area with technology is likely to involve some sort of development - although it is unclear if this could involve merely a different price or wider availability or interoperability. ${ }^{115}$ A different approach to abuse may be required, therefore, to enable the European Commission to require that access be provided. Opportunities for this do lie in existing EU competition law and also by looking to human rights.

First, in the Microsoft case the European Commission considered that regard should be had to the entirety of the circumstances, ${ }^{116}$ and in the IMS case, decided shortly after this decision, the European Court said that it was sufficient (so not mandatory) for the test set out above to be met. ${ }^{117}$ As noted in relation to identification of essential technologies, competition law has also begun to intervene in the pharmaceutical field, ${ }^{118}$ in the very seeking of IP $^{119}$ and the approaches to IP owners to other forms of regulation, ${ }^{120}$ on the basis of the abuse provision but looking beyond the test set out above. Investigations have also been launched into Google. ${ }^{121}$ So, this proactive approach suggests that the Commission might choose to investigate and be willing to take a wider approach to abuse and one which would enable wider access in extreme cases. ${ }^{122}$

Notwithstanding the points made above regarding the importance of human rights in the decision-making of EU institutions, human rights have not played a role in the IP and competition EU decisions which have been discussed. There has been a more developed relationship in South Africa. As discussed in this collection by Onazi, legislation was passed to facilitate greater access to HIV/AIDS medicines in the light of the constitutional rights to life and to health, with the legislation permitting parallel importing and compulsory licensing of patented pharmaceutical drugs. ${ }^{123}$ The legislation was challenged by international pharmaceutical companies, including on the basis of the obligations of South Africa under TRIPS. There were strong arguments that the legislation was in any event consistent with TRIPS. ${ }^{124}$ The case was settled - and arguably precipitated international outrage and steps to facilitate greater access. ${ }^{125}$ Action was also taken in South Africa in 2002 when a complaint was made to the Competition Commission by patients, doctors, a trade union and an activist group against pharmaceutical companies regarding their excessive pricing of treatments for HIV/AIDS. This case was based on abuse of a dominant position, although there is 
one reference to human rights initiatives in the pleading. ${ }^{126}$ This case was also settled, in return for an agreement regarding licensing to generic manufacturers. ${ }^{127}$ So, even in South Africa, there has not been a decision where pleadings have had a combination of IP, competition and human rights at the heart of the matter.

The EU legal framework, which has competition and human rights as key parts of the TFEU, and developed means of respecting and managing the power and rights of IP, should be able to bring about a combination of the three fields. The European Commission could build on the more expansive approaches taken in the pharmaceutical industry and in Microsoft to be more willing to require sharing, notwithstanding the IP. When considering whether or not this is appropriate in a particular case, the European Commission should have regard in particular to the human rights involved and whether or not they favour greater access.

In terms of how this would work, all decisions to be made regarding the market and abuse should be consistent with the prevailing weight of the human rights interests in question. An example of this was considered in relation to the southern European seeds above. In that situation, human rights, on balance, might favour the provision of access to deliver rights to life and food rather than the right to property and reward of the IP owner.

The next stage would be market definition. If the human rights are weighted against the patent owner, then it is proposed that if it would be tenable (adopting established market definition approaches) to find the market the same as the technology, then the European Commission must do so - even if it might otherwise have preferred a different approach. If this approach is not tenable, the Commission cannot take the narrow approach. A wider definition might still lead to a situation where the IP owner is in a dominant position, but there may be others in the market. If this is so, then, as we have seen, the technology would not be essential. This is not a situation, therefore, in which one should argue for a more expanded approach to abuse. But if an IP owner does control an essential technology, then if the human rights balance is against the IP owner, a wider approach should be taken to abuse, and the IP owner should be required to share. ${ }^{128}$

The final decision for the European Commission would be the basis on which the IP owner would be required to share. There is a strong link with the fair, reasonable and non-discriminatory principle which is developing in relation to standards as discussed above. ${ }^{129}$ It may be argued that these payments do not provide an adequate reward to the provider; but perhaps it is a fair reward in the sense considered by Onazi. Further, as discussed above, this situation will arise only in rare cases, 
where a holistic balance of the wide range of legal principles suggests that interests other than the reward of the innovator should take precedence.

\subsection{CONCLUSION}

From a practical perspective, this chapter has argued that there is merit in identifying essential technologies and a means of delivering greater access when they exist. It also moves from seeing the debate as merely about IP being the heart of innovation; it considers how best to address fundamental questions of climate change and human rights, and of the contribution which can be made by a full range of technologies, both essential and non-essential. It discusses the potential for states to develop other new forms of encouraging innovation, such as open standards, so far as is possible given regional and international obligations in respect of competition and IP.

From a more fundamental perspective, this chapter has seen that there is a place for each of three key legal fields in the arguments made. One, or two, cannot achieve as much. IP, competition and human rights can each assist in identifying essential technologies, with the key role ultimately played by competition. Human rights can encourage more openness and greater access to all technologies, but IP can prevent this, as can competition in some cases. And when there is an essential technology protected by IP, the EU competition framework could be developed, in the light of the existing relevant human rights framework, to require that access be provided to it.

Finally, it should be borne in mind that, for ease, reference has been made frequently throughout this chapter to 'a technology'. But, as is inherent in the discussion of standards and interoperability, and as was noted at the start of this chapter, more than one technology will frequently be involved in a product. Access to more than one technology may be required. The discussion regarding standards and calls for further action notes that this issue is well recognized. ${ }^{130}$ If the proposal made in the section above should be necessary, competition complaints may be required against more than one IP owner in respect of a technology set. This is not an appealing approach - but the prospect of it might suffice to encourage a different attitude by IP owners. 


\section{NOTES}

1. See Kyoto Protocol 1998 to the United Nations Framework Convention on Climate Change 2303 UNTS 148, available at http://unfccc.int/kyoto_protocol/items/ 2830.php, in particular Arts 2 and 3. For details of ratification, see http://unfccc.int/ kyoto_protocol/status_of_ratification/items/2613.php.

2. See A.E.L. Brown et al., Towards a Holistic Approach to Technology and Climate Change: What Would Form Part of an Answer?, University of Edinburgh School of Law Working Paper 2010/32 (25 October 2010) 1, 2, 4, 5-8, available at http://ssrn.com/abstract=1697608 ('Joint Working Paper').

3. Occasionally regional, e.g., Community Trade Mark in the EU; for details and sources see http://oami.europa.eu/ows/rw/pages/index.en.do, although there is no patent equivalent; note that there is also EU copyright law from the perspective of harmonization, e.g., Directive 2001/29/EC on the harmonization of certain aspects of copyright and related rights in the information society, available at http://eurlex.europa.eu/LexUriServ/LexUriServ.do?uri=CELEX:32001L0029:EN:HTML; and the prospect of more EU IPRs is set out in the Treaty of Lisbon, Art. 18 [2007] OJ C306 (17 December 2007), available at http://europa.eu/lisbon_treaty/full_text/ index_en.htm.

4. See e.g., F.M. Scherer, 'The innovation lottery' in R.C. Dreyfuss, D.L. Zimmerman and H. First (eds), Expanding the Boundaries of Intellectual Property: Innovation Policy for the Knowledge Society (Oxford University Press, Oxford/New York, 2001); R.P. Merges, 'Of property rules, Coase, and intellectual property' (1994) 94 Columbia Law Review 2655 and in R. Towse and R. Holzhauer (eds), The Economics of Intellectual Property, vol. I, Introduction and Copyright, International Library of Critical Writing in Economics 145 (Edward Elgar Publishing Ltd, Cheltenham, 2002) 8, 95, respectively.

5. See Joint Working Paper, n. 2 above, at 23-4.

6. See e.g., in the United Kingdom, Patents Act (PA) 1977, s.25 (20 years) and Copyright, Designs and Patents Act (CDPA) 1988, ss.12-15 (in most cases life of the author plus 70 years).

7. United Kingdom: PA 1977, s.60; CDPA 1988, s.16; Trade Marks Act (TMA) 1994, s.9.

8. CDPA 1988, s.16(3); PA 1977, s.60(1); TMA 1994, s.10.

9. See Paris Convention 1883, Art. 5A, and in the United Kingdom, PA 1977, s.48A with regard to compulsory licensing and ss.55-58 regarding Crown use; with respect to copyright, see CPDA 1988, s.116 et seq.

10. Annex 1C, see www.wto.org/english/tratop_e/trips_e/t_agm0_e.htm.

11. See e.g., Arts 2, 3, 4, 9, 10 TRIPS.

12. For a list of WTO members, see www.wto.org/english/thewto_e/whatis_e/tif_e/ org6_e.htm.

13. With regard to copyright, see Art. 9 TRIPS.

14. With regard to patents, see Art. 27(1) TRIPS.

15. With regard to patents, Art. 27(2) and (3) TRIPS and see E. Derclaye, 'Should patent law help cool the planet? An enquiry from the point of view of environmental law: Part II' (2009) 31(5) EIPR 227.

16. See references at n. 4 above, also discussion in Santamauro, Chapter 3.

17. Hargreaves, Review of Intellectual Property and Growth (2011) 59-60, available at www.ipo.gov.uk/ipreview.htm ('Hargreaves Review').

18. For example, Amcor compostable packaging, see www.amcor.com/about_us/media_ centre/news/28389534.html. 
19. See e.g., Aquamarine Power, 'Aquamarine in European funding bid' (12 May 2011), available at www.aquamarinepower.com/news/aquamarine-power-ineuropean-funding-bid/, in relation to the development of the first 'large-scale grid connected' wave energy system.

20. See Joint Working Paper, n. 2 above, at 8; Feist Publications Inc. v. Rural Telephone Service Co., 499 U.S. 340 (1991).

21. See http://maps.google.com/intl/en/help/maps/streetview/\#utm_campaign=en\&utm _ medium=van\&utm_source=en-van-na-us-gns-svn; for the views of the UK Information Commissioner in November 2010, see ICO Press Release, 'Information Commissioner announces outcome of Google Street View investigation' (3 November 2010), available at www.ico.gov.uk/ /media/documents/pressreleases/2010/ google_inc_street_view_press_release_03112010.ashx, and regarding future developments see Information Commissioner Office, 'ICO Statement on information received from Google about retention of Street View data' (27 July 2012), available at www.ico.gov.uk/news/latest_news/2012/statement-ico-responseto-information-received-from-google-27072012.aspx.

22. AA Route Planner, see www.theaa.com/route-planner/index.jsp, although as is explored further below in relation to competition, other options may exist, for example, in this context, from the RAC, see www.rac.co.uk/route-planner/.

23. For a completed project exploring this from the perspective of education, see http://edina.ac.uk/projects/grade/.

24. For example, the Carbon Trust which was found not to be a public authority and as such not open to consideration for disclosure: see ICO Decision 2004FS50154684 on Freedom of Information Act 2000 (Section 50) and Environmental Information Regulations 2004, available at www.ico.gov.uk/upload/documents/decisionnotices/ 2009/fs_50154684.pdf.

25. Freedom of Information Act 2000, s.50 and Environmental Information Regulations 2004, SI 2004/3391. An application under this to the University of East Anglia led to disputes regarding the extent to which information regarding the extent of climate change had been provided; this is referred to by Navraj Singh Ghaleigh in Chapter 2 and see also information and statements in CRU Update 2 (24 November 2009), available at www.uea.ac.uk/mac/comm/media/press/2009/nov/CRUupdate; these events led to the Information Commissioner's Office News Release, 'ICO issues advice on the disclosure of research information' (26 September 2011), available at www.ico.gov.uk/news/latest_news/2011/ico-issues-advice-on-the-disclosure-ofresearch-information-26092011.aspx (this includes link to guidance).

26. See consideration in UK Information Commissioner's Office Decision Notice FER0072933 on Freedom of Information Act 2000 and Environmental Information Regulations 2004 (11 September 2006) paras 36-56, regarding details of location of mobile phone masts and the relationship between the information legislation and database and copyright legislation, available at www.ico.gov.uk/upload/documents/ decisionnotices/2006/decision_notice_fer0072933.pdf.

27. See e.g., Island of Eigg in Scotland, the subject of commentary by C. Ottery, 'Eigg Islanders win top prize for green living', Guardian, 11 July 2010, available at www.guardian.co.uk/environment/2010/jul/01/eigg-island-renewable-energy.

28. Examples of which were discussed at the International Telecommunications Union Green Standards Week, September 2011, see www.itu.int/ITU-T/climatechange/ gsw/201102/index.html; and also form part of the World Wildlife Clean Development Mechanism Gold Standard, seehttp://wwf.panda.org/what_we_do/how_we_ work/businesses/climate/offsetting/gold_standard/, as discussed by Ghaleigh (Chapter 2) and by Morgera and Kulovesi, Chapter 5. 
29. For overview, see www.openstandards.net/viewOSnet3C.jsp?showModuleName= about, and for an example from another field, see World Wide Web Consortium, www.w3.org/Consortium/, http://www.w3.org/standards/.

30. For a scholarly perspective, see A. Fitzgerald and K. Pappalardo, 'Moving towards open standards' (2009) 6(2) SCRIPTed 467, available at www.law.ed.ac.uk/ahrc/ script-ed/vol6-2/fitzgerald.asp; M. Välimäki and V.Oksanen, 'Patents on compatibility standards and open source: do patent law exceptions and royalty-free requirements make sense?' (2005) 2(3) SCRIPTed 397, available at www. law.ed.ac.uk/ahrc/script-ed/vol2-3/valimaki.asp; J. Cave et al., Trends in Connectivity Technologies and their Socioeconomic Impacts, Final Report of the Study 'Policy Options for the Ubiquitous Internet Society' (2009) ('RAND Report'), available at www.rand.org/content/dam/rand/pubs/technical_reports/2009/RAND_ TR776.pdf; and M. Dolmans and C. Piana, 'A tale of two tragedies' (2010) 2(2) IFOSSLR 115. See also L. DeNardis, Access to Online Information and Knowledge: Opening Standards, Opening Human Liberty (2009), available at www.giswatch. org/hi/node/155.

31. See e.g., M.A. Lemley, 'Intellectual property rights and standard-setting organizations' (2002) 90 Calif. L Rev. 1889. Regarding competition challenges to the setting of standards and the exercise of them, see e.g., Sel Imperial Ltd v. British Standards Institution [2010] EWHC 854 (Ch) and Der Grune Punkt-Duales System Deutschland GmbH v. European Commission (T-151/01) [2007] ECR II-1607.

32. Standards rules may exist in respect of the meaning of 'essential', although when courts have been asked to consider this courts have taken their own view, see Nokia Corp. v. Interdigital Technology Corp. [2007] EWHC 3077 (Pat).

33. See e.g., European Telecommunications Standards Institute on IP with policies and rules, available at www.etsi.org/WebSite/AboutETSI/IPRsInETSI/IPRsinETSI.aspx, in particular Arts 6, 8, 14 and W3, see www.w3.org/Consortium/Patent-Policy-2004 0205.

34. See ITU, www.itu.int/en/ITU-T/Workshops-and-Seminars/patent/Pages/default.aspx.

35. See www.snia-europe.org/en/Download/document-summary.cfm?docid=0B4286841B54-4441-991BD318373B761B.

36. See 'ISO 14000: Environmental Management', available at www.iso.org/iso/iso_ catalogue/management_standards/environmental_management.htm.

37. See www.sunspec.org/. For details of activity, see e.g., www.sunspec.org/2012/10/ bankable-data-interoperability-standards/.

38. See e.g., P.A. Geroski, 'Intellectual property rights, competition policy and innovation: is there a problem?' (2005) 2(4) SCRIPTed 422, available at www. law.ed.ac.uk/ahrc/script-ed/vol2-4/geroski.asp; P. Regibeau and K. Rockett, 'The relationship between intellectual property law and competition law: an economic approach' in S.D. Anderman (ed.), The Interface Between Intellectual Property Rights and Competition Policy (Cambridge University Press, Cambridge, 2007).

39. Volvo AB v. Erik Veng (UK) Ltd (238/87) [1988] ECR 6211.

40. Article 345 TFEU. See consideration in Etablissements Consten SARL v. Commission of the European Economic Community (56 and 58/64) [1966] ECR 299 at 345, para. 10.

41. See e.g., IMS Health GmbH \& Co. OHG v. NDC Health GmbH \& Co. KG (C-418/01) [2004] 4 CMLR 28; Microsoft Case COMP/C-3/37, available at www.microsoft.com/presspass/download/legal/europeancommission/03-24-06EU Decision.pdf; and Microsoft Corp. v. European Commission (T-201/04) [2007] 5 ECR II-3601.

42. ITT Promedia NV v. European Commission (T-111/96) [1998] ECR II-2937; cf. Intel Corp. v. VIA Technologies Inc. [2002] EWCA Civ 1905, [2003] FSR 33. 
43. EC Commission Opening of Proceedings COMP 39.246, available at http:// ec.europa.eu/competition/antitrust/cases/dec_docs/39246/39246_951_10.pdf; and J. Straus, 'Patent application: obstacle to innovation and abuse of dominant position under Article 102 TFEU?' (2010) J Competition Law and Practice 1.

44. Rambus case no. COMP 138.636; Europa Press Release, 'Commission confirms sending statement of objections to Rambus' (23 August 2007), available at http:// europa.eu/rapid/pressReleasesAction.do?reference=MEMO/07/330\&forma; and regarding settlement, Europa Press Release, 'Antitrust: Commission accepts commitments from Rambus lowering memory chip royalty rates - frequently asked questions' (9 December 2009), available at http://europa.eu/rapid/ pressReleasesAction.do?reference $=\mathrm{MEMO} / 09 / 544 \&$ format $=$ HTML\&aged $=1 \&$ language $=E N \&$ guiLanguage $=$ en .

45. See Joint Working Paper, n. 2 above, at 8; M.A. Lemley and D. McGowan, 'Legal implications of economic network effects' (1998) 86 Calif. L Rev. 479.

46. For detailed discussion, see H. Ullrich, 'Patents and standards: a comment on the German Federal Supreme Court decision Orange Book Standard' (2010) 41(3) IIC 337.

47. See B \& I Line Plc v. Sealink Harbours Ltd and Sealink Stena Ltd, decision of European Commission [1992] 5 CMLR 255 and discussion in U. Muller and A. Rodenhausen, 'The rise and fall of the essential facility doctrine' (2008) 29(5) ECLR 310.

48. See e.g. D. Kanter, 'IP and compulsory licensing on both sides of the Atlantic: an appropriate antitrust remedy or a cutback on innovation?' (2006) 27(7) ECLR 351; A. Andreangeli, 'Interoperability as an "essential facility" in the Microsoft case: encouraging competition or stifling innovation?' (2009) 34(4), EL Rev. 584; and Oscar Bronner GmbH \& Co. KG v. Mediaprint Zeitungs- und Zeitschriftenverlag GmbH \& Co. KG (C-7/97) [1998] ECR I-7791, Opinion of the Advocate General, para. 33 et seq.

49. See Attheraces v. British Horseracing Board [2007] ECC 7.

50. Commission Notice on the definition of the relevant market for the purposes of Community competition law [1997] OJ C-372/03 and see also Commission Notice Guidelines on the application of Article 81 of the EC Treaty to technology transfer agreements (2004) paras 22 and 25, available at http://eur-lex.europa.eu/LexUri Serv/LexUriServ.do?uri=OJ:C:2004:101:0002:0042:EN:PDF ('TT Guidelines').

51. United Brands Co. v. European Commission (27/76) [1978] ECR 207 at para. 65.

52. For more detailed discussion of this, and the contribution of human rights, see A. Brown, 'Human rights, competition law and access to essential technologies' in I. Brown (ed.), Research Handbook on Governance of the Internet (Edward Elgar, Cheltenham, forthcoming 2013).

53. See also Mary Robinson Foundation Climate Justice Project, available at www.mr fcj.org.

54. International Covenant on Civil and Political Rights 1966 ('ICCPR'), Art. 6 (1966) 999 UNTS 171.

55. International Covenant on Economic, Social and Cultural Rights 1966 ('ICESCR'), Art. 11(1) and (2) (1966) 003 UNTS 3.

56. Ibid. Art. 12.

57. Ibid. Art. 15(b) and (c).

58. Joint Working Paper, n. 2 above, at 19 and recital 7 of the Resolution of the Human Rights Council of the Office of the High Commissioner for Human Rights, 25 March 2009, available at www2.ohchr.org/english/issues/climatechange/docs/ resolution10_4.doc.

59. Johnston v. Chief Constable of the Royal Ulster Constabulary (222/84) [1986] ECR 1651 para. 18. Note also ongoing discussions about the EU becoming a party to the 
ECHR, pursuant to Art. 6 of the Treaty on European Union (Consolidated Versions of the Treaty on European Union and the Treaty Establishing the European Community [2006] OJ C321E; for status see www.coe.int/lportal/web/coe-portal/ what-we-do/human-rights/eu-accession-to-the-convention.

60. Articles 2, 10 of and Protocol 1, Art. 1 to the ECHR and Anheuser-Busch Inc. v. Portugal (73049/01) [2007] ETMR 24.

61. Charter of Fundamental Rights of the European Union [2007] OJ C303/01 ('EU Charter'); Treaty on European Union, Art. 6(1). Note also Protocol on the Application of the Charter of Fundamental Rights of the European Union to Poland and to the United Kingdom, Treaty of Lisbon 2007, Art. 1 [2007] OJ C306 which provides that the EU Charter shall not extend the ability of the European Court of Justice or national courts to find that laws or actions of the United Kingdom or Poland are inconsistent with fundamental rights.

62. Article 17(2) EU Charter; see C. Geiger, 'Intellectual property shall be protected!? Article 17(2) of the Charter of Fundamental Rights of the European Union: a mysterious provision with an unclear scope' (2009) 31(3) EIPR 113, and N. MacCormick, 'Human rights and competition law: possible impact of the proposed EU Constitution' (2005) 2(4) SCRIPTed 444 at 445-7, available at www.law. ed.ac.uk/ahrc/script-ed/vol2-4/maccormick.asp.

63. Article $37 \mathrm{EU}$ Charter.

64. Article 6(2) Treaty on European Union [1992] OJ C/191.

65. See e.g., Eugen Schmidberger Internationale Transporte Planzuge v. Austria (C-112/00) [2003] ECR I-5659 at para. 71.

66. Since Internationale Handelsgesellschaft v. Einfuhr-und Vorratsstelle fur Getreide und Futtermittel (11/70) [1970] ECR 1125 at para. 4.

67. Levi Strauss \& Co. v. Tesco Stores Ltd [2002] EWHC 1625, [2003] RPC 18 at paras 40, 42; Ashdown v. Telegraph Group Ltd [2001] EWCA Civ 1142, [2002] Ch. 149 at paras 25, 28, 30, 31, 39, 43, 45 and General Comment No. 17 (2005) paras 1, 3, 4, 7, 10, 22-4, 35, available at www.unhchr.ch/tbs/doc.nsf/(Symbol)/E.C.12.GC.17. En?OpenDocument.

68. Campbell v. MGN Ltd [2002] UKHL 22 at para. 140.

69. See material at 'Innovation and the Lisbon Strategy', available at http://europa.eu/ legislation_summaries/other/n26021_en.htm.

70. See http://ec.europa.eu/europe2020/index_en.htm.

71. Decision 1639/2006 [2006] OJ L310/15.

72. See http://ec.europa.eu/cip/eip/index_en.htm, run by the Directorate-General for Enterprise and Industry and Environment.

73. See http://ec.europa.eu/enterprise/policies/innovation/support/index_en.htm.

74. $\operatorname{COM}(2010) 546$ final (6 October 2010); see 'Innovation Union' at 19 and commitments 21-23, available at http://ec.europa.eu/research/innovation-union/pdf/ innovation-union-communication_en.pdf.

75. Innovation Union, n. 74 above, at 15, 16, commitment 16.

76. Ibid. commitments 20, 21.

77. See comments by Commissioner Kroes set out in Europa Press Release SPEECH/ 10/300, 'Neelie Kroes address at Open Forum Europe 2010 Summit' (10 June 2010), available at http://europa.eu/rapid/pressReleasesAction.do?reference= SPEECH/10/300, and Digital Agenda for Europe, http://ec.europa.eu/information society/digital-agenda/index_en.htm.

78. See http://ec.europa.eu/cip/ict-psp/index_en.htm run by the Directorate-General for Media and Information Society.

79. See http://ec.europa.eu/information_society/activities/ict_psp/documents/ict_psp_wp 2011_for_publication.pdf. 
80. See www.wbcsd.org/templates/TemplateWBCSD5/layout.asp?type=p\&MenuId=M TQ3NQ\&doOpen=1\&ClickMenu=LeftMenu and http://creativecommons.org/; see Joint Working Paper, n. 2 above, at 30.

81. See www.dndi.org/press-releases/866-sanofi-dndi-agreement.html.

82. See Joint Working Paper, n. 2 above, at 11, 16.

83. For discussion about the state aid and procurement issues which might arise from these policies, see the contribution by James McLean (Chapter 10).

84. All agreements between undertakings, decisions by associations of undertakings and concerted practices which may affect trade between Member States and which have as their object or effect the prevention, restriction or distortion of competition within the common market, and in particular those which (a) directly or indirectly fix purchase or selling prices or any other trading conditions; (b) limit or control production, markets, technical development, or investment ... (d) apply dissimilar conditions to equivalent transactions with other trading parties, thereby placing them at a competitive disadvantage.

85. Article 101(1) and (2) TFEU.

86. For overview, see M. Glader, Innovation, Markets and Competition Analysis (Edward Elgar, Cheltenham, 2006) 59 et seq.; cf. previous attitudes in the United States, the 'Nine No Nos' of the 1970s set out by Bruce B. Wilson, Deputy Assistant Attorney General, Antitrust Division, before the Michigan State Bar Antitrust Law Section, 21 September 1972, available at www.cptech.org/cm/ ninenonos.html; and in Regulation (EC) 240/96 of 31 January 1996 on the application of Article 85(3) of the Treaty to certain categories of technology transfer agreements [1996] OJ L31.

87. Regulation (EC) $772 / 2004$ on the application of Article 81 (3) of the Treaty to categories of technology transfer agreements [2004] OJ L123 (which applies only to agreements with two parties, see recital 1, Art. 2) and TT Guidelines, n. 50 above.

88. TT Guidelines, n. 50 above, at 152, 167, 224, 225, 227, 231-2.

89. Ibid. para. 231.

90. See http://ec.europa.eu/competition/consultations/2010_horizontals/guidelines_en. pdf.

91. 2010 Draft, n. 90 above, paras 252-3, 256, 258-62, 266-7, 269-90, 300-30, 304-9, 314.

92. Ibid. paras 252, 300, 319, 320.

93. Ibid. paras 265, 307-9.

94. See http://ec.europa.eu/competition/consultations/2010_horizontals/index.html.

95. J. Drexl et al., 'Comments of the Max Planck Institute for Intellectual Property and Tax Law on the draft Commission Block Exemption Regulation on Research and Development Agreements and the draft guidelines on horizontal cooperation agreements' (2010) 41(8) IIC 948 at para. 46, although there is only one reference to open standards.

96. See http://ec.europa.eu/competition/consultations/2010_horizontals/digitaleurope _ en.pdf. See also from a scholarly perspective M. Glader, 'Open standards: public policy aspects and competition law requirements' (2010) 6(3) Euro CJ 611.

97. Guidelines on the applicability of Article 101 of the Treaty on the Functioning of the European Union to horizontal cooperation agreements [2011] OJ C11, see in particular section 7. See also S. Sattler, 'Standardisation under EU competition rules: the Commission's new horizontal guidelines' (2011) 32(7) ECLR 343.

98. Horizontal Agreements Guidelines, n. 97 above, section 6.

99. Ibid. paras 287-90.

100. See e.g., support for the Anti-Counterfeiting Trade Agreement, see commentary at P.K. Yu, 'Six secret (and now open) fears of ACTA (June 14, 2010)' (2011) 64 SMU Law Review, and also proposal for a secret Trans-Pacific Agreement, see the 
Electronic Frontier Foundation sources, at https://secure.eff.org/site/Advocacy? $\mathrm{cmd}=$ display \&page $=$ UserAction $\& \mathrm{id}=471$.

101. See also Joint Working Paper, n. 2 above, at 8-22. Regarding ongoing collaborations, see UNEP, EPO and ICTSD, Patents and Clean Energy: Bridging the Gap Between Evidence and Policy (2010), available at www.unep.ch/etb/events/UNEP\% 20EPO\%20ICTSD\%20Event\%2030\%20Sept\%202010\%20Brussels/Study\%20 Patents\%20and\%20clean\%20energy_15.9.10.pdf.

102. Re ICCPR, n. 54 above, see Human Rights Committee, www2.ohchr.org/english/ bodies/hrc/; and regarding ICESCR, n. 55 above, Committee on ESCR, www2.ohchr.org/english/bodies/cescr/; and M. Bowman, 'Towards a unified treaty body for monitoring compliance with UN human rights conventions? Legal mechanisms for treaty reform' (2007) 7(1) HRL Rev. 224.

103. See http://ec.europa.eu/energy/gas_electricity/acer/acer_en.htm.

104. See http://ec.europa.eu/dgs/environment/index_en.htm.

105. See http://ec.europa.eu/dgs/clima/mission/index_en.htm.

106. See http://fra.europa.eu/fraWebsite/home/home_en.htm.

107. Kyoto Protocol 1998 to the United Nations Framework Convention on Climate Change 2303 UNTS 148. Note that this chapter does not pursue the extent to which the EU institutions should have regard to the responsibilities of the EU under the Kyoto Protocol; see discussion in M. Morgera, K. Kulovesi and M. Muñoz, 'Environmental integration and multi-faceted international dimensions of EU law: unpacking the EU's 2009 climate and energy package' (2011) 48(3) Common Market Law Review 829.

108. Opinion C-1/09 on Draft agreement: creation of a unified patent litigation system, available at $\mathrm{http}: / /$ curia.europa.eu/juris/liste.jsf?language $=$ en $\&$ num $=1 / 0$; see para. 65, relying on Van Gend en Loos (26/62) [1963] ECR 1 at 12 and paras 72, 78.

109. European Council, 'Creating a Unified Patent Litigation System: orientation debate', 10630/11 (26 May 2011) 154, available at http://register. consilium.europa.eu/pdf/en/11/st10/st10630.en11.pdf; and for ongoing developments see IPkat, e.g., http://ipkitten.blogspot.co.uk/2012/09/breaking-updated-draftagreement-on.html.

110. See e.g., Productores de Musica de Espana (Promusicae) v. Telefonica de Espana SAU (C-275/06) [2008] 2 CM.R 17 and L'Oreal SA v. Bellure NV (C-487/07) [2010] Bus. LR 303.

111. Intel Corp. v. Via Technologies Inc., n. 42 above, paras 51, 90.

112. After exhaustion of national remedies, see Arts 1 and 34 ECHR. Generally, see P. Leach, Taking a Case to the European Court of Human Rights, Blackstone's Human Rights Series (3rd edn, Oxford University Press, Oxford, 2011).

113. Council Regulation (EC) $1 / 2003$ on the implementation of the rules on competition laid down in Articles 81 and 82 of the Treaty, Art. 5 [2003] OJ L1.

114. Radio Telefis Eireann v. European Commission (C-241/91 P) [1995] ECR I-743 at paras 54-6; IMS, n. 41 above, at paras 28-9, 38-45 and 51 (noting that IMS involved a standard); and Microsoft, decision of Court of First Instance, n. 41 above, at paras 560-703. See also discussion in V. Korah, 'The interface between intellectual property rights and competition in developed countries' (2005) 2(4) SCRIPTed 429, available at www.law.ed.ac.uk/ahrc/script-ed/vol2-4/korah.asp.

115. See D. Howarth and K. McMahon, "Windows has performed an illegal operation": the Court of First Instance's judgment in Microsoft v Commission' (2008) 29(2) ECLR 117 at 123.

116. European Commission, Microsoft, n. 41 above, at para. 558.

117. IMS, n. 41 above, at para. 38 .

118. See also 'Pharmaceuticals: Sector Inquiry', available at http://ec.europa.eu/comm/ competition/sectors/pharmaceuticals/inquiry/index.html. 
119. As regards the coming to the end of the investigation into Boehringer in this respect, see Boehringer Press Release, 'Investigation of the European Commission' (1 April 2007), available at www.boehringer-ingelheim.com/news/news_releases/press_ releases/2007/01_april_2007.html.

120. Astra Zeneca, Commission Decision COMP/A. 37.507/F3 of 15 June 2005 relating to a proceeding under Article 82 of the EC Treaty and Article 54 of the EEA Agreement, available at http://eur-lex.europa.eu/LexUriServ/LexUriServ.do?uri= CELEX:32006D0857:EN:NOT ('Astra Zeneca') regarding abuse, see paras 325-8 and 602-862, in particular 741-9. See J.P. Gunther and C. Breuvart, 'Misuse of patent and drug regulatory approval systems in the pharmaceutical industry: an analysis of US and EU converging approaches' (2005) 26(12) ECLR 669; J. Galloway , 'Astra Zeneca v European Commission' (2010) 31(1) ECLR 536. This decision was upheld by the General Court in July 2010: Astra Zeneca AB v. European Commission (T-321/05) [2010] 5 CMLR 28 at paras 54, 356, 357, 671-2 and 676. In late 2012, an appeal had been heard and a decision is awaited.

121. European Commission Press Release, 'Antitrust: Commission probes allegations of antitrust violations by Google' (30 November 2010), available at http://europa.eu/ $\mathrm{rapid} /$ pressReleasesAction.do?reference $=\mathrm{IP} / 10 / 1624 \&$ format=HTML\&aged $=0 \&$ language $=E N \&$ guiLanguage $=$ en .

122. See also DG Competition, Staff Discussion Paper on the Application of Article 82 of the Treaty to Exclusionary Abuses (2005) 237-9, available at http://ec.europa.eu/ comm/competition/antitrust/others/discpaper2005.pdf.

123. Medicines and Related Substances Control Act 1965, s.15(c), as amended by the Medicines and the Related Substances Control Amendment Act 1997.

124. See discussion in E. Cameron and J. Berger, 'Patents and public health: principle, politics and paradox', Inaugural British Academy Law Lecture (19 October 2004), available at www.law.ed.ac.uk/ahrb/script-ed/docs/cameron.asp.

125. D. Matthews, 'The role of international NGOs in the intellectual property policymaking and norm-setting activities of multilateral institutions' (2007) 82(3) ChiKent Law Review 1369.

126. See draft complaint (September 2002), available at www.cptech.org/ip/health/cl/taccomplaint.doc, especially paras 61 and 99 and E.S. Nwauche, 'Human rights: relevant considerations in respect of IP and competition law' (2005) 2(4) SCRIPTed 467 at $482-3$, available at www.law.ed.ac.uk/ahrc/script-ed/vol2-4/enyinna.asp.

127. In respect of the difficulties which arose regarding the consultation and scope of the settlement reached, see details in Case 61/CAC/Apr06, Appeal Court judgment, available at www.comptrib.co.za/cases/appeal/retrieve_case/625.

128. For more detailed discussion of these themes, see A.E.L. Brown, Intellectual Property, Human Rights and Competition: Access to Essential Innovation and Technology (Edward Elgar, Cheltenham, 2012).

129. For discussion, see also D. Geradin, Pricing Abuses by Essential Patent Owners in a Standard-Setting Context (July 2008), available at http://papers.ssrn.com/sol3/ papers.cfm?abstract_id=1174922; cf. R. Schalensee, Standard-Setting, Innovation Specialists, and Competition Policy (April 2009), available at http://papers.ssrn.com/ sol3/papers.cfm?abstract_id=1219784.

130. See also Hargreaves Review, n. 17 above, at 9, 55-9, available at www.ipo.gov.uk/ ipreview.htm. 